\title{
IMPLIKASI AKTA PERNYATAAN NOTARIS TERHADAP PERALIHAN HAK ATAS TANAH DALAM PROGRAM PENGAMPUNAN PAJAK (TAX AMNESTY)
}

\author{
Siti Nurul Intan Sari Dalimunthe \\ Fakultas Hukum, Universitas Pembangunan Nasional "Veteran" Jakarta \\ Email:sinuinsada@yahoo.com \\ Khoirul Rizal Lutfi \\ Fakultas Hukum, Universitas Pembangunan Nasional "Veteran" Jakarta \\ Email:irul.rizal@ymail.com
}

\begin{abstract}
ABSTRAK
Pemerintah mensahkan dan mengundangkan Undang-Undang Nomor 11 Tahun 2016 tentang Pengampunan Pajak (Tax Amnesty) yang bertujuan meningkatkan penerimaan pajak negara untuk pembiayaan pembangunan. Pada Pasal 15 ayat 2 UU Tax Amnesty, Notarislah yang diberikan kewenangan membuat Surat Pernyataan yang dibuat dalam bentuk Akta Pernyataan oleh para pihak yang mengikuti program Tax Amnesty, dalam pengalihan hak atas tanah dan bangunan. Selama ini, dalam prakteknya, berdasarkan PP Pendaftaran Tanah Nomor 24 Tahun 1997 dan PP Peraturan Jabatan Pejabat Pembuat Akta Tanah Nomor 24 Tahun 2016, akta otentik yang berhubungan dengan pengalihan hak atas tanah dan bangunan dibuat oleh PPAT bukan Notaris. Penelitian ini bertujuan untuk (1) mengetahui Peran Notaris terhadap Peralihan hak atas tanah dalam Program Tax Amnesty dan (2) mengkaji implikasi Akta Pernyataan Notaris terhadap Peralihan Hak atas Tanah dalam Program Tax Amnesty. Hasil penelitian menunjukkan Peran Notaris terhadap Peralihan hak atas tanah dalam Program Tax Amnesty adalah membantu para pihak dalam menuangkan perjanjian balik nama/pengalihan harta ke dalam bentuk akta otentik sampai melegalisasi dokumen-dokumen penting untuk keperluan Tax Amnesty. Akta Pernyataan yang dibuat oleh Notaris berimplikasi terhadap peralihan hak atas tanah dalam Program Pengampunan Pajak dengan memberikan kepastian hukum sebagai dasar balik nama sertifikat di BPN.
\end{abstract}

Kata Kunci: Akta Pernyataan Notaris, Perlaihan Hak Atas Tanah, Tax Amnesty

\begin{abstract}
The government approve and legislate the Law No. 11 of 2016 Regarding Tax Amnesty, which aims to increase state tax revenues for financing development. In the article 15 paragraph 2 on the act of tax amnesty, the notary is given the authority to make a statement in the form of a statement deed by the parties that participated in the tax amnesty program, in diversion rights of land and buildings. So far in the practice, based on government regulation of the Republic of Indonesia No. 24 of 1997 on Land Registration and government regulation No. 24 of 2016 on the amendment to government regulation No. 37 of 1998 on position
\end{abstract}


regulation of the land deed maker officer, the authentic deed that relating to the transfer of rights to land and buildings made by Land Deed Official and not with a Notary Public. This research aims to (1) knowing the Notary Public Role on the Transition of land rights in the Tax Amnesty Program, and (2) review the implications of the Notary's Deed of Statement on the Transition of Land Rights in the Tax Amnesty Program. The results showed that the role of the Notary Public on the transfer of land rights in the Tax Amnesty Program was to assist the parties in pouring back the name/transfer of property agreements in the form of authentic deeds to legalize important documents for Tax Amnesty needs. The Deed of Statement that made by a Notary Public has the implications for the transfer of land rights in the Tax Amnesty Program by providing legal certainty as the basis for returning the name of the certificate to the National Land Agency, where the land is located.

Keywords: Notarial Deed Statement, Transition of Land Rights, Tax Amnesty.

\section{PENDAHULUAN}

Indonesia sebagai Negara berkembang yang melakukan pembangunan di segala bidang, memerlukan pendanaan untuk mencukupi pembangunan tersebut. Sumber pendanaan negara berasal dari pendapatan negara yang berasal dari tiga sektor yaitu pajak, penerimaan negara bukan pajak serta penerimaan hibah dari dalam dan luar negeri. Salah satu sumber pendapatan negara yang memiliki kontribusi cukup besar adalah Pajak. Berdasarkan Pasal 1 Undang-Undang Nomor 16 Tahun 2009 tentang Ketentuan Umum dan Tata Cara Perpajakan, Pajak adalah kontribusi wajib kepada negara yang terutang oleh orang pribadi atau badan yang bersifat memaksa berdasarkan Undang-Undang, dengan tidak mendapatkan imbalan secara langsung dan digunakan untuk keperluan negara bagi sebesarbesarnya kemakmuran rakyat.

Seperti yang telah kita ketahui bahwa tingkat pertumbuhan ekonomi di Indonesia dalam belakangan ini cenderung melambat yang memiliki dampak menurunnya penerimaan pajak dan ketersediaan likuiditas dalam negeri berkurang. Padahal ketersediaan likuiditas tersebut sangat dibutuhkan dalam meningkatkan pertumbuhan ekonomi. ${ }^{1}$

Pada tanggal 1 Juli 2016 Pemerintah Republik Indonesia mensahkan dan mengundangkan Udang-Undang Nomor 11 tahun 2016 tentang Pengampunan

\footnotetext{
${ }^{1}$ Tax Amnesty Indonesia 2016, "Latar Belakang dan Tujuan Tax Amnesty", http://taxamnestyindonesia2016.blogspot.com/2016/08/latar-belakang-dan-tujuan-taxamnesty.html, diakses 20 November 2018.
} 
Pajak (selanjutnya disebut Udang-Undang Pengampunan Pajak) yang salah satu tujuannya adalah meningkatkan penerimaan pajak negara untuk pembiayaan pembangunan. Melalui program Pengampunan Pajak (Tax Amnesty) yang diselenggarakan pemerintah ini, setiap wajib pajak berhak mendapatkan pengampunan pajak melalui pengungkapan harta yang dimilikinya dalam surat pernyataan.

Ada yang menarik dalam Undang-Undang Pengampunan Pajak tersebut, Pada Pasal 15 ayat 1 Undang-Undang Pengampunan Pajak, menyebutkan bahwa pengalihan hak atas harta tidak bergerak berupa tanah yang belum dibalik namakan atas nama Wajib Pajak, harus melakukan pengalihan hak menjadi atas nama Wajib Pajak. Lebih lanjut dalam Pasal 15 ayat 2, Pengalihan hak sebagaimana dimasud dibebaskan dari pengenaan Pajak Penghasilan, dalam hal permohonan pengalihan hak atau penandatanganan surat pernyataan oleh kedua belah pihak di hadapan Notaris. Pada Pasal 15 ayat 2 Undang-Undang Tax Amnesty tersebut, surat pernyataan pengalihan hak atas harta tidak bergerak berupa tanah dibuat bukan dilakukan dengan menggunakan akta Pejabat Pembuat Akta Tanah (selanjutnya disebut PPAT), melainkan di hadapan Notaris.

Selama ini, peralihan hak atas tanah dapat dilakukan dengan dua cara, yaitu beralih dan dialihkan. Beralih artinya berpindah hak atas tanah dari pemegang haknya kepada pihak lain karena suatu peristiwa hukum. Dialihkan artinya berpindahnya hak atas tanah dari pemegang hak atas tanah kepada pihak lain karena suatu perbuatan hukum, sehingga hak atas tanah yang bersangkutan sengaja dialihkan kepada pihak lain.

Sebagaimana dalam Pasal 37 Peraturan Pemerintah Nomor 24 Tahun 1997, dasar dari pendaftaran tanah dalam peralihan hak atas tanah adalah melalui akta otentik yang dibuat oleh PPAT. Namun, dalam Undang-Undang Pengampunan Pajak, mengamanatkan Notaris dalam Pembuatan Akta Pernyataan yang menuangkan pernyataan peralihan hak atas tanah dan bangunan kepada Wajib Pajak yang mengikuti Program Pengampunan Pajak (Tax Amnesty). Undang-Undang Pengampunan Pajak menjadi dasar yang baru bagi jabatan Notaris dalam membuat akta yang selama ini dibuat oleh PPAT dalam membuat 
akta yang berhubungan dengan perbuatan hukum dalam peralihan hak atas tanah dan bangunan.

Oleh karena itu, peneliti tertarik untuk melakukan penelitian dengan rumuskan permasalahan sebagai berikut :

1. Bagaimana peran Notaris terhadap peralihan hak atas tanah dalam program pengampunan pajak (Tax Amnesty)?

2. Bagaimana implikasi Akta Pernyataan yang dibuat oleh Notaris terhadap peralihan hak atas tanah dalam program pengampunan pajak (Tax Amnesty)?

\section{METODE PENELITIAN}

Penelitian hukum dilihat dari tujuannya sendiri terdiri dari penelitian hukum normatif dan penelitian hukum sosiologis atau empiris. ${ }^{2}$ Jenis penelitian yang digunakan dalam penelitian ini merupakan penelitian hukum normatifempiris. Secara normatif, penelitian ini mengacu kepada norma-norma serta asas hukum yang terdapat dalam peraturan perundang-undangan, sedangkan secara empiris atau sosiologis dengan melihat sesuatu kenyataan hukum di dalam masyarakat. Penelitian ini bersifat deskriptif karena ingin mengungkapkan kebenaran hukum terkait Peran Notaris dan implikasi Akta Pernyataan Notaris terhadap peralihan hak atas tanah dalam program Pengampunan Pajak (Tax Amnsety).

\section{PEMBAHASAN}

\section{A. Akta Otentik}

Menurut bentuknya, akta dapat dibagi menjadi akta otentik dan akta di bawah tangan. Berdasarkan Pasal 1868 Kitab Undang-Undang Hukum Perdata (selanjutnya disebut KUHPerdata), suatu akta otentik adalah yang sedemikian, yang dibuat dalam bentuk yang ditentukan oleh Undang-Undang oleh atau Pejabat Umum yang berwenang untuk itu, ditempat akta itu dibuat.

KUHPerdata memberikan batasan unsur yang dimaksud dengan akta otentik, yaitu : ${ }^{3}$

\footnotetext{
${ }^{2}$ Soerjono Soekanto, Pengantar Penelitian Hukum, (Jakarta : UI Press, 2006), hal. 43.

${ }^{3}$ Habib Adjie, Kebatalan dan Pembatalan Akta Notaris, (Bandung : Refika Aditama, 2013), hal. 6 .
} 
a.) Akta itu harus dibuat oleh (door) atau dihadapan (ten overstaan) seorang pejabat umum.

b.) Akta itu harus dibuat dalam bentuk yang ditentukan oleh UndangUndang.

c.) Pegawai umum (pejabat umum) oleh atau dihadapan siapa akta itu dibuat, harus mempunyai wewenang untuk membuat akta tersebut.

Pelaksanaan Pasal 1868 KUHPerdata tersebut, pembuat Undang-Undang harus membuat peraturan perundang-undangan untuk menunjuk para pejabat umum yang berwenang untuk membuat akta otentik dan oleh karena itulah para Notaris ditunjuk sebagai pejabat yang sedemikian berdasarkan Peraturan Jabatan Notaris maupun Undang-Undang Jabatan Notaris. ${ }^{4}$

Kewenangan Notaris dalam Membuat Akta Otentik diatur dalam Pasal 1 angka 1 Undang-Undang Nomor 2 Tahun 2014 tentang Perubahan atas UndangUndang Nomor 30 Tahun 2004 tentang Jabatan Notaris (selanjutnya disebut UUJN), Notaris adalah Pejabat Umum yang berwenang untuk membuat akta otentik dan memiliki kewenangan lainnya sebagaimana yang dimaksud dalam undang-undang ini atau berdasarkan undang-undang lainnya.

Bahwa akta sebagaimana akta yang mempunyai kekuatan pembuktian adalah Akta Notaris, yaitu akta otentik yang memiliki kekuatan hukum dengan jaminan kepastian hukum sebagai alat bukti tulisan yang sempurna (volledig bewijs) tidak memerlukan tambahan alat pembuktian lain dan hakim terikat karenanya. ${ }^{5}$

Akta mempunyai dua fungsi : fungsi formil (formalitas causa) dan fungsi alat bukti (probationis causa). Formalitas Causa artinya akta berfungsi untuk lengkapnya atau sempurnanya suatu perbuatan hukum, jadi bukan sahnya perbuatan hukum. Dalam konteks ini, akta merupakan syarat formil untuk adanya suatu perbuatan hukum. Probationis causa berarti akta mempunyai fungsi sebagai alat bukti, karena sejak awal akta tersebut dibuat dengan sengaja untuk pembuktian di kemudian hari. Sifat tertulisnya suatu perjanjian dalam bentuk akta ini tidak membuat sahnya perjanjian tetapi hanyalah agar dapat digunakan sebagai

\footnotetext{
${ }^{4}$ G.H.S. Lumban Tobing, Peraturan Jabatan Notaris, (Jakarta, Erlangga, 1983), hal. 33.

${ }^{5}$ A.A.Andi Prajidno, Apa dan Siapa Notaris di Indonesia?, Cetakan Pertama, (Surabaya : Putra Media Nusantara, 2010), hal.51.
} 
alat bukti di kemudian hari. Kekuatan pembuktian akta ini dibedakan menjadi tiga macam : 6

a.) Kekuatan pembuktian lahir (kekuatan pembuktian yang didasarkan pada keadaan lahir, apa yang tampak pada lahirnya (acta publica probant sese espa).

b.)Kekuatan Pembuktian Formil (memberikan kepastian tentang peristiwa bahwa pejabat yang dan para pihak menyatakan dan melakukan apa yang dimuat dalam akta).

c.) Kekuatan pembuktian materil (memberikan kepastian tentang materi suatu akta).

Akta yang dibuat Notaris memiliki kekuatan pembuktian yang sempurna dibandingkan akta dibawah tangan yang dibuat sendiri oleh para pihak yang berkepentingan tanpa adanya bantuan pejabat umum.

\section{B. Program Pengampunan Pajak (Tax Amnesty) sebagai Amanat Undang- \\ Undang Nomor 11 Tahun 2016 tentang Pengampunan Pajak}

Pembangunan nasional Negara Kesatuan Republik Indonesia yang bertujuan untuk memakmurkan seluruh rakyat Indonesia yang merata dan berkeadilan, memerlukan pendanaan besar yang bersumber utama dari penerimaan pajak. Untuk memenuhi kebutuhan penerimaan pajak yang terus meningkat, diperlukan kesadaran dan kepatuhan masyarakat dengan mengoptimalkan semua potensi dan sumber daya yang ada. Namun, pada kenyataannya, kesadaran dan kepatuhan masyarakat dalam melaksanakan kewajiban perpajakannya masih perlu ditingkatkan karena terdapat Harta, baik di dalam maupun di luar negeri yang belum atau belum seluruhnya dilaporkan dalam Surat Pemberitahuan Tahunan Pajak Penghasilan. Oleh karena itu, pemerintah dalam meningkatkan penerimaan Negara dan pertumbuhan perekonomian serta kesadaran dan kepatuhan masyarakat dalam pelaksanaan kewajiban perpajakan menerbitkan kebijakan Pengampunan Pajak (Tax Amnesty).

\footnotetext{
${ }^{6}$ Arief Rachman, Akta Otentik dalam Hukum Positif di Indonesia, https://notarisarief.wordpress.com/2011/05/15/akta-otentik-dalam-hukum-positif-indonesia, diakses 28 September 2018.
} 
Pada tanggal 1 Juli 2016, Pemerintah Republik Indonesia mensahkan dan mengundangkan Undang-Undang Nomor 11 Tahun 2016 tentang Pengampunan Pajak yang bertujuan meningkatkan penerimaan pajak negara untuk pembiayaan pembangunan. Pengertian dari Pengampunan Pajak (Tax Amnesty) menurut Pasal 1 angka 1 Undang-Undang Pengampunan Pajak adalah penghapusan pajak yang seharusnya terhutang, tidak dikenai sanksi administrasi perpajakan dan sanksi pidana di bidang perpajakan, dengan cara mengungkap harta dan membayar uang tebusan sebagaimana diatur dalam undang-undang ini. Masyarakat yang pembayaran pajaknya selama ini masih belum sesuai dengan kondisi nyata diharapkan mengikuti Tax Amnesty dengan cara melaporkan seluruh harta kekayaannya kepada negara dan membayar uang tebusan agar mendapatkan pengampunan pajak.

Subyek dari Tax Amnesty diatur dalam Pasal 1 angka 2 Undang-Undang Pengampunan Pajak, yaitu Wajib Pajak,yang merupakan orang pribadi atau badan yang mempunyai hak dan kewajiban perpajakan sesuai dengan ketentuan perundan-undangan di bidang perpajakan. Wajib Pajak yang dimaksud adalah yang memiliki Nomor Pokok Wajib Pajak (NPWP). Wajib pajak dapat berupa individu, badan hukum ataupun pengusaha yang memiliki omset seperti Usaha Mikro Kecil Menengah (UMKM). Sedangkan, Subyek pajak yang belum memiliki NPWP yang akan mengikuti program ini, dapat mendaftarkan dirinya terlebih dahulu di Kantor Pelayanan Pajak (KPP) untuk mendapatkan NPWP.

Obyek dari Tax Amnesty berdasarkan Pasal 1 angka 3 Undang-Undang Pengampunan Pajak adalah harta wajib pajak berupa akumulasi tambahan kemampuan ekonomis berupa seluruh kekayaan, baik yang berwujud maupun tidak terwujud, baik bergerak maupun tidak bergerak, digunakan untuk usaha maupun bukan untuk usaha yang berada di dalam dan/atau di luar negeri yang dilaporkan kepada negara untuk mendapatkan pengampunan pajak,dengan cara melunasi seluruh tunggakan pajak yang dimiliki dan membayar uang tebusan.berlaku sejak disahkannya Undang-undang nomor 11 tahun 2016 yaitu 1 Juni 2016 hingga 31 Maret 2017.

Bila harta tersebut baru dimiliki tahun 2016, tidak dapat dilakukan program pengampunan pajak, dikarenakan fasilitas pengampunan ini hanya untuk 
perbuatan hukum yang dilakukan sebelum tahun 2015 dan belum dilaporkan oleh wajib pajak dalam Surat Pemberitahuan Tahunan (SPT) sebelumnya.

\section{Kewenangan Notaris dalam Program Pengampunan Pajak (Tax Amnesty)}

Menurut Habib Adjie, kewenangan Notaris dalam Pasal 15 dari ayat 1 sampai dengan ayat 3 UUJN, dapat dibagi menjadi tiga kewenangan $:^{7}$

1. Kewenangan Umum Notaris.

2. Kewenangan Khusus Notaris.

3. Kewenangan notaris yang akan ditentukan kemudian.

Kewenangan umum Notaris (membuat akta secara umum) terdapat dalam Pasal 15 ayat 1 UUJN, Notaris berwenang membuat Akta autentik mengenai semua perbuatan, perjanjian, dan penetapan yang diharuskan oleh peraturan perundang-undangan dan/atau yang dikehendaki oleh yang berkepentingan untuk dinyatakan dalam Akta autentik, menjamin kepastian tanggal pembuatan Akta, menyimpan Akta, memberikan grosse, salinan dan kutipan Akta, semuanya itu sepanjang pembuatan Akta itu tidak juga ditugaskan atau dikecualikan kepada pejabat lain atau orang lain yang ditetapkan oleh undang-undang.

Kewenangan Khusus Notaris, terdapat dalam Pasal 15 ayat 2 UUJN, yang mengatur mengenai kewenangan khusus notaris untuk melakukan tindakan hukum tertentu :

a.) mengesahkan tanda tangan dan menetapkan kepastian tanggal surat di bawah tangan dengan mendaftar dalam buku khusus;

b.) membukukan surat di bawah tangan dengan mendaftar dalam buku khusus;

c.) membuat kopi dari asli surat di bawah tangan berupa salinan yang memuat uraian sebagaimana ditulis dan digambarkan dalam surat yang bersangkutan;

d.) melakukan pengesahan kecocokan fotokopi dengan surat aslinya;

e.) memberikan penyuluhan hukum sehubungan dengan pembuatan Akta;

f.) membuat Akta yang berkaitan dengan pertanahan; atau

g.) membuat Akta risalah lelang.

${ }^{7}$ Habib Adjie. Hukum Notaris Indonesia, Tafsir Tematik Terhadap UU No.30 Tahun 2004 Tentang Jabatan Notaris, (Bandung: Rafika Aditama, 2008), hal. 78. 
Selanjutnya, dalam Pasal 15 ayat 3, selain kewenangan umum dan khusus, Notaris mempunyai kewenangan lain yang diatur dalam peraturan perundangundangan. Yang dimaksud dalam Pasal 15 ayat (3) UUJN dengan kewenangan yang akan ditentukan kemudian adalah wewenang yang berdasarkan aturan hukum lain yang akan datang kemudian (ius constituendum). Wewenang notaris yang akan ditentukan kemudian, merupakan wewenang yang akan ditentukan berdasarkan peraturan perundang-undangan. Batasan mengenai apa yang dimaksud dengan peraturan perundang-undangan ini dapat dilihat dalam Pasal 1 angka 2 Undang-Undang Nomor 5 Tahun 1986 tetang Peradilan Tata Usaha Negara, bahwa ${ }^{8}$ :

"Yang dimaksud dengan peraturan perundang-undangan dalam undang-undang ini ialah semua peraturan yang bersifat mengikat secara umum yang dikeluarkan oleh Badan Perwakilan Rakyat Bersama Pemerintah baik di tingkat pusat maupun di tingkat daerah, serta semua keputusan badan atau pejabat tata usaha negara, baik di tingkat pusat maupun tingkat daerah, yang juga mengikat secara umum."

Dengan disebutnya Notaris di dalam Pasal 15 Undang-Undang Pengampunan Pajak, membuat Notaris turut andil dalam Program Pengampunan Pajak (Tax Amnesty) dimana Notaris dalam hal ini berperan sebagai pembuat surat pernyataan dari kedua belah pihak yang menyatakan bahwa harta wajib pajak adalah benar milik wajib pajak yang menyampaikan Surat Pernyataan, dalm hal harta tersebut belum dapat diajukan permohonan pengalihan hak. Wajib Pajak yang mengikuti Program Pengampunan Pajak (Tax Amnesty) selama ini, meminjam nama orang lain dalam bukti kepemilikan hartanya berupa harta tidak bergerak berupa tanah dan/atau bangunan dan/atauharta berupa saham. Sehingga dengan Program Pengampunan Pajak ini, Wajib Pajak dapat mengalihkan hak atas hartanya ke nama wajib pajak.

Pasal 15 Undang-Undang Pengampunan Pajak, berbunyi :

(1) Wajib Pajak yang telah memperoleh Surat Keterangan dan membayar uang tebusan atas:

a. Harta tidak bergerak berupa tanah dan/atau bangunan; dan/atau

b. Harta berupa saham, yang belum dibaliknamakan atas nama Wajib Pajak, harus melakukan pengalihan hak menjadi atas nama Wajib Pajak.

(2) Pengalihan hak sebagaimana dimaksud pada ayat (1) huruf a dibebaskan dari pengenaan Pajak Penghasilan, dalam hal: 
a. permohonan pengalihan hak; atau

b. penandatanganan surat pernyataan oleh kedua belah pihak di hadapan notaris yang menyatakan bahwa Harta sebagaimana dimaksud pada ayat (1) huruf a adalah benar milik Wajib Pajak yang menyampaikan Surat Pernyataan, dalam hal Harta dimaksud belum dapat diajukan permohonan pengalihan hak, dilakukan dalam jangka waktu paling lambat tanggal 31 Desember 2017.

(3) Pengalihan hak sebagaimana dimaksud pada ayat (1) huruf b dibebaskan dari pengenaan Pajak Penghasilan dalam hal terdapat perjanjian pengalihan hak dalam jangka waktu paling lambat tanggal 31Desember 2017.

(4) Apabila sampai dengan tanggal 31 Desember 2017, Wajib Pajak tidak mengalihkan hak sebagaimana dimaksud pada ayat (1), atas pengalihan hak yang dilakukan dikenai pajak sesuai dengan ketentuan peraturan perundangundangan yang mengatur mengenai Pajak Penghasilan.

Surat pernyataan yang dimaksud dalam Pasal 15 ayat 2 UndangUndang Pengampunan Pajak tersebut dituangkan dalam betuk akta otentik, dikarenakan produk hukum yang dibuat oleh Notaris adalah keinginan para pihak yang dituangkan dalam bentuk akta otentik.

Undang-Undang Pengampunan Pajak, tidak menentukan jenis dan judul akta apa yang harus dibuat oleh Notaris. Pada dasarnya akta-akta yang dibuat terkait dengan Program Tax Amnesty adalah akta yang biasa dibuat oleh notaris. Hanya saja mesti diperhatikan dalam pembuatan akta khususnya berkenaan dengan penentuan jenis akta dan klausula yang terkandung dalam akta terkait.

Oleh karena itu, jelaslah bahwa kewenangan Notaris dalam membuat akata otentik dalam Program Pengampunan Pajak (Tax Amnesty) merupakan amanat Undang-Undang Pengampunan Pajak yang merupakan kewenangan Notaris yang ditentukan kemudian berdasarkan peraturan perundang-undangan yang bersifat mengikat secara umum yang dikeluarkan yang dikeluarkan oleh Badan Perwakilan Rakyat Bersama Pemerintah yaitu Undang-Undang Pengampunan Pajak.

\section{Akta Pernyataan Notaris}

Akta Pernyataan yang dibuat oleh Notaris sebagaimana yang didasarkan dalam ketentuan Pasal 15 ayat 2 Undang-Undang Pengampunan Pajak dibuat oleh Notaris dalam rangka Program Pengampunan Pajak (Tax Amnesty). Dalam Undang-Undang tersebut tidak ditentukan judul akta apa yang harus dibuat, namun beberapa Notaris menggunakan judul akta dengan "Akta Pernyataan". 
Akta Pernyataan ini dibuat untuk menyatakan bahwa Harta tidak bergerak berupa tanah dan/atau bangunan dan/atau harta berupa saham, yang belum dibaliknamakan atas nama Wajib Pajak, harus melakukan pengalihan hak menjadi atas nama Wajib Pajak adalah benar milik Wajib Pajak yang membuat Pernyataan.

Akta inilah yang dipakai oleh Wajib Pajak untuk mengalihkan kepemilikan hak atas harta tidak bergeraknya berupa tanah dan bangunan, yang dijadikan dasar balik nama di BPN. Seperti yang diketahui, selama ini pembuatan Akta yang berhubungan dengan akta pertanahan sebagai dasar peralihan hak atas tanah ke BPN (Badan Pertanahan Nasional) menjadi kewenangan PPAT (Pejabat Pembuat Akta Tanah), misalnya Akta Jual Beli, Akta Pembagian Hak Bersama, Akta Hibah dan lain-lain.

\section{E. Peralihan Hak Atas Tanah}

Hak Atas Tanah adalah hak yang memberikan wewenang kepada yang mempunyai hak untuk menggunakan atau mengambil manfaat dari tanah yang dihakinya. ${ }^{9}$ Kata "menggunakan" mengandung pengertian bahwa hak atas tanah digunakan untuk kepentingan mendirikan bangunan, misalnya rumah, toko, hotel, kantor, pabrik. Kata "mengambil manfaat" mengandung pengertian bahwa hak atas tanah digunakan untuk kepentingan bukan mendirikan bangunan, misalnya untuk kepentingan pertanian, perikanan, pertenakan, perkebunan. ${ }^{10}$

Salah satu sifat hak atas tanah adalah dapat beralih dan dialihkan kepada pihak lain. Ada 2 (dua) bentuk peralihan hak atas tanah ${ }^{11}$ :

1. Beralih

Beralih artinya berpindah hak atas tanah dari pemegang haknya kepada pihak lain karena suatu peristiwa hukum. Contoh peristiwa hukum adalah meninggal duni8a seseorang, jika pemegang suatu hak atas tanah meninggak dunia, maka hak atas tanah tersebut secara yuridis berpindah atau beralih kepada ahli warisnya sepanjang ahli warisya memenuhi

${ }^{9}$ Urip Santoso, Pendaftaran dan Peralihan Hak atas Tanah, Cetakan I, (Jakarta : Prenada Media Group, 2010), hal. 49; dikutip dari Soedikno Mertokusumo, Hukum dan Politik Agraria, (Jakarta : Karunika-Universitas Terbuka,1988), hal.47.

${ }^{10}$ Ibid.

${ }^{11}$ Ibid., hlm.63. 
syarat sebagai subyek hak dari obyek hak atas tanah yang diwariskan. Hak atas tanah sudah berpindah secara yuridis kepada ahli waris sejak pemegang hak atas tanah sebagai pewaris.

2. Dialihkan

Dialihkan artinya berpindahnya hak atas tanah dari pemegang hak atas tanah kepada pihak lain karena suatu perbuatan hukum, sehingga hak atas tanah yang bersangkutan sengaja dialihkan kepada pihak lain. Bentuk pemindahan haknya antara lain :

a) Jual beli;

b) Tukar menukar;

c) Hibah;

d) Pemasukan dalam perusahaan atau inbreng;

e) Hibah-wasiat atau legaat.

Dalam program pengampunan pajak (Tax Amnesty), harta tidak bergerak berupa tanah dan/atau bangunan, yang akan dibaliknamakan atas nama Wajib Pajak, merupakan peralihan hak atas tanah yang sengaja dialihkan kepada pihak lain melalui suatu perbuatan hukum.

\section{F. Perbedaan Kewenangan Notaris dan PPAT}

Pengertian dan dasar hukum mengenai Notaris dalam UUJN telah disebutkan sebelumnya diatas, sedangkan PPAT (Pejabat Pembuat Akta Tanah) dalam pasal 1 angka 1 Peraturan Pemerintah Republik Indonesia Nomor 24 Tahun 2016 Tentang Perubahan Atas Peraturan Pemerintah Nomor 37 Tahun 1998 Tentang Peraturan Jabatan Pejabat Pembuat Akta Tanah (selanjutnya disebut PP PPAT) adalah pejabat umum yang diberikan kewenangan untuk membuat akta-akta otentik mengenai perbuatan hukum tertentu mengenai hak atas tanah atau Hak Milik Atas Satuan Rumah Susun.

Pengangkatan dan pemberhentian jabatan Notaris dilakukan oleh Menteri Hukum dan Hak Asasi Manusia Republik Indonesia sedangkan pengangkatan PPAT berdasarkan Surat Keputusan Menteri Negara Agraria dan Tata Ruang/Kepala Badan Pertanahan Nasional Republik Indonesia. 
Dari segi tugas dan wewenang, Notaris mempunyai tugas dan wewenang membuat akta otentik mengenai semua perbuatan, perjanjian, dan ketetapan yang diharuskan oleh peraturan perundang-undangan dan/atau yang dikehendaki oleh yang berkepentingan untuk dinyatakan dalam akta otentik, menjamin kepastian tanggal pembuatan akta, menyimpan akta, memberikan grosse, salinan dan kutipan akta, semuanya itu sepanjang pembuatan akta-akta itu tidak juga ditugaskan atau dikecualikan kepada pejabat lain atau orang lain yang ditetapkan oleh UUJN dan kewenangan lainnya sebagaimana dalam dalam Pasal 15 UUJN. Sedangkan tugas dan kewenangan PPAT tercantum dalam pasal 2 ayat 1 PP PPAT, yaitu bertugas pokok melaksanakan sebagian kegiatan pendaftaran tanah dengan membuat akta sebagai bukti telah dilakukannya perbuatan hukum tertentu mengenai hak atas tanah atau Hak Milik Atas Satuan Rumah Susun, yang akan dijadikan dasar bagi pendaftaran perubahan data pendaftaran tanah yang diakibatkan oleh perbuatan hukum itu.Perbuatan hukum yang dimaksud adalah:
a. Jual beli;
b. Tukar menukar;
c. Hibah;
d. Pemasukan ke dalam perusahaan (inbreng);
e. Pembagian hak bersama;
f. Pemberian Hak Guna Bangunan/Hak Pakai atas tanah Hak Milik;
g. Pemberian Hak Tanggungan;
h. Pemberian kuasa membebankan Hak Tanggungan.

Akta yang dibuat oleh PPAT sebagai bukti telah dilakukannya perbuatan hukum tertentu mengenai hak atas tanah atau Hak Milik Atas Satuan Rumah Susun dapat dijadikan dasar perlaihan hak atas tanah dan bangunan untuk balik nama di BPN. Hal ini ditegaskan dalam Pasal 37 ayat 1 Peraturan Pemerintah Nomor 24 Tahun 1997 tentang Pendaftaran Tanah, yang berbunyi : Peralihan hak atas tanah dan hak milik atas satuan rumah susun melalui jual beli, tukar menukar, hibah, pemasukan dalam perusahaan dan perbuatan hukum pemindahan hak lainnya, kecuali pemindahan hak melalui lelang, hanya dapat didaftarkan, jika dibuktikan dengan akta yang dibuat oleh PPAT yang berwenang menurut ketentuan peraturan perundang-undangan yang berlaku. 
Pada Pasal 15 ayat 2 huruf f UUJN, Notaris juga mempunyai kewenangan untuk membuat akta yang berkaitan dengan pertanahan. Ada tiga penafsiran dari pasal tersebut $^{12}$ :

1. Notaris telah mengambil alih semua wewenang PPAT menjadi wewenang notaris atau telah menambah wewenang notaris.

2. Bidang pertanahan juga ikut menjadi wewenang notaris.

3. Tidak ada pengambil alihan wewenang dari PPAT ataupun dari notaris, karena baik PPAT maupun notaris telah mempunyai wewenang sendirisendiri.

Jika kita melihat dari sejarah diadakannya notaris dan PPAT itu sendiri maka akan nampak bahwa memang notaris tidak berwenang untuk membuat akta di bidang pertanahan. PPAT telah dikenal sejak sebelum kedatangan bangsa penjajah di negeri Indonesia ini, dengan berdasar pada hukum adat murni yang masih belum diintervensi oleh hukum-hukum asing. Pada masa itu dikenal adanya (sejenis) pejabat yang bertugas untuk mengalihkan hak atas tanah di mana inilah yang merupakan cikal bakal dari keberadaan PPAT di Indonesia. Dengan demikian, dapat dilihat bahwa lembaga PPAT yang kemudian lahir hanya merupakan kristalisasi dari pejabat yang mengalihkan hak atas tanah dalam hukum adat. Adapun mengenai keberadaan notaris di Indonesia yang dimulai pada saat zaman penjajahan Belanda ternyata sejak awal memang hanya memiliki kewenangan yang terbatas dan sama sekali tidak disebutkan mengenai kewenangan notaris untuk membuat akta di bidang pertanahan. ${ }^{13}$

Namun, hal ini akan menjadi riskan jika kita melihat hierarki peraturan yang mengatur mengenai keberadaan dan wewenang kedua pejabat negara ini. Keberadaan notaris ditegaskan dalam suatu Undang-Undang yang di dalamnya menyebutkan bahwa seorang notaris memiliki kewenangan untuk membuat akta di bidang pertanahan. Sedangkan keberadaan PPAT diatur dalam suatu Peraturan Pemerintah yang secara hierarki tingkatannya lebih rendah jika dibandingkan dengan Undang-Undang Jabatan Notaris yang mengatur keberadaan dan

\footnotetext{
${ }^{12}$ Habib Adjie, 2008, Op. Cit., hal. 84.

${ }^{13}$ Zulham Umar, Kewenangan, Kewajiban Dan Larangan Notaris Dalam UUJN, https://zulpiero.wordpress.com/2010/04/26/kewenangan-kewajiban-dan-larangan-notaris-dalamuujn/, diakses 29 Oktober 2018.
} 
wewenang Notaris. Sampai sekarang pun hal ini masih menjadi perdebatan di berbagai kalangan baik pakar hukum maupun notaris dan/atau PPAT itu sendiri. Jalan tengah yang dapat diambil adalah bahwa notaris juga dapat memiliki wewenang di bidang pertanahan, sepanjang bukan wewenang yang telah ada pada PPAT. $^{14}$

\section{G. Peran Notaris Terhadap Peralihan Hak Atas Tanah dalam Program Pengampunan Pajak}

Akta Notaris bersumber dari ketentuan Pasal 1 angka 1 Undang-Undang Nomor 2 Tahun 2014 Tentang Perubahan Atas Undang-Undang Nomor 30 Tahun 2004 Tentang Jabatan Notaris jo Pasal 1868 KUHPerdata, Notaris adalah pejabat umum yang berwenang untuk membuat akta autentik dan memiliki kewenangan lainnya sebagaimana dimaksud dalam Undang-Undang ini atau berdasarkan undang-undang lainnya. Artinya kewenangan Notaris membuat akta autentik didasarkan dari Undang-Undang Jabatan Notaris yaitu pada Pasal 15 dan dapat berdasarkan ketentuan Undang-Undang lainnya.

Penunjukkan Undang-Undang Pengampunan Pajak terhadap Jabatan Notaris sudah tepat, sebagaimana ketentuan Pasal 1 angka 1 Undang-Undang Jabatan Notaris yang memberikan kewenangan terhadap Notaris untuk membuat akta autentik berdasarkan ketentuan Undang-Undang lainnya. Selain itu, dalam Pasal 15 ayat 2 huruf f Undang-Undang Jabatan Notaris, Notaris juga mempunyai kewenangan untuk membuat akta yang berkaitan dengan pertanahan. Namun, kewenangan Notaris dalam membuat akta pertanahan tersebut masih sulit untuk diimplementasikan di lapangan, mengingat Badan Pertanahan Nasional (BPN) hanya menerima untuk mencatatkan dan memproses akta yang berkaitan dengan pertanahan yang dibuat oleh PPAT berdasarkan peraturan-peraturan yang telah diuraikan sebelumnya.

Untuk mendapatkan data pada penelitian ini, selain menelaah peraturan Perundang-Undangan yang berhubungan dengan penelitian ini, peneliti juga

${ }^{14}$ Zulham Umar, Kewenangan, Kewajiban Dan Larangan Notaris Dalam UUJN, https://zulpiero.wordpress.com/2010/04/26/kewenangan-kewajiban-dan-larangan-notaris-dalamuujn/, diakses 29 Oktober 2018. 
mewawancarai dua orang Notaris yang berada di Kota Depok, yaitu Notaris Errizka F Bey, SE, SH, M.Kn dan Notaris Tasya Amanda, SH., M.Kn.

Undang-Undang Pengampunan Pajak memberi peran yang sangat penting kepada Notaris untuk membantu para wajib pajak yang ikut dalam mendapatkan fasilitas pengampunan pajak. Dalam program ini, Notaris berperan mulai dari menuangkan perjanjian balik nama/pengalihan harta ke dalam bentuk Akta Pernyatan hingga melegalisasi dokumen penting untuk Program Pengampunan Pajak, seperti Surat Pernyataan Harta untuk Pengampunan Pajak. ${ }^{15}$

Peran ini dinilai penting karena apa yang dilakukan oleh Notaris merupakan bentuk perbuatan yang dipersyaratkan oleh Pasal 15 Undang-Undang Pengampunan Pajak, yang berbunyi sebagai berikut :

(1) Wajib Pajak yang telah memperoleh Surat Keterangan dan membayar uang tebusan atas:

a. Harta tidak bergerak berupa tanah dan/atau bangunan; dan/atau

b.Harta berupa saham, yang belum dibaliknamakan atas nama Wajib Pajak, harus melakukan pengalihan hak menjadi atas nama Wajib Pajak.

(2) Pengalihan hak sebagaimana dimaksud pada ayat (1) huruf a dibebaskan dari pengenaan Pajak Penghasilan, dalam hal:

a. permohonan pengalihan hak; atau

b. penandatanganan surat pernyataan oleh kedua belah pihak di hadapan notaris yang menyatakan bahwa Harta sebagaimana dimaksud pada ayat (1) huruf a adalah benar milik Wajib Pajak yang menyampaikan Surat Pernyataan, dalam hal Harta dimaksud belum dapat diajukan permohonan pengalihan hak, dilakukan dalam jangka waktu paling lambat tanggal 31 Desember 2017.

(3) Pengalihan hak sebagaimana dimaksud pada ayat (1) huruf b dibebaskan dari pengenaan Pajak Penghasilan dalam hal terdapat perjanjian pengalihan hak dalam jangka waktu paling lambat tanggal 31Desember 2017.

(4) Apabila sampai dengan tanggal 31 Desember 2017, Wajib Pajak tidak mengalihkan hak sebagaimana dimaksud pada ayat (1), atas pengalihan hak yang dilakukan dikenai pajak sesuai dengan ketentuan peraturan perundangundangan yang mengatur mengenai Pajak Penghasilan.

Adapun hal-hal yang harus dilakukan oleh Wajib Pajak dan Peran Notaris dalam Program Pengampunan Pajak adalah ${ }^{16}$ :

1. Wajib pajak harus mempunyai NPWP (Nomor Pokok Wajib Pajak) dan mendatangi KPP (Kantor Pelayanan Pajak) dimana Wajib Pajak terdaftar sesuai NPWP. Jika belum, Notaris meminta wajib pajak untuk membuat

\footnotetext{
${ }^{15}$ Wawancara dengan Errizka F Bey, SE, SH, M.Kn, Notaris di Kota Depok

${ }^{16}$ Wawancara dengan Errizka F Bey, SE, SH, M.Kn, Notaris di Kota Depok
} 
NPWP terlebih dahulu di KPP sesuai daerah tempat tinggal sebagai Wajib Pajak.

2. Setelah memiliki NPWP, wajib bisa menanyakan hal detail mengenai prosedur hingga tarif tebusan untuk ikut pengampunan pajak. Wajib pajak yang menyatakan ikut dalam program Pengampunan Pajak harus melakukan pembayaran uang tebusan sesuai batas waktu yang ditetapkan yaitu tanggal 31 Desember 2017 dengan mengisi formulir dan pernyataan (Untuk memperoleh Pengampunan Pajak, Wajib Pajak harus menyampaikan surat Kepada Menteri berdasarkan Pasal 10 ayat 1 Undang-Undang Pengampunan Pajak). Dalam hal ini, Notaris dapat melegalisasi dokumen penting untuk Program Pengampunan Pajak, seperti Surat Pernyataan Harta untuk Pengampunan Pajak.

3. Setelah itu, membayar uang tebusan yang dibayarkan kepada kas negara melalui bank Persepsi (Pasal 10 ayat 4 Undang-Undang Pengampunan Pajak).

4. Setelah membayar uang tebusan, dikeluarkan Surat Keterangan Pengampunan Pajak dari Kepala Kantor Wilayah.

5. Wajib Pajak mendapatkan Surat Keterangan Pengampunan Pajak dari Kepala Kantor Wilayah

6. Setelah mendapatkan Surat Keterangan Pengampunan Pajak dari Kepala Kantor Wilayah DJP, Wajib Pajak dapat memperlihatkan kepada Notaris untuk dibuatkan akta Pernyataan.

7. Notaris harus meneliti terlebih dahulu kelengkapan berkas para pihak, mulai dari KTP, Surat Keterangan Pengampunan Pajak dan tambahan SKB (Surat Keterangan Bebas) pemotongan dan atau pemungutan Pajak Penghasilan dari Kepala Kantor Pelayanan Pajak tempat menyampaikan SPT. (Pasal 15 ayat 2 Undang-Undang Pengampunan Pajak).

8. Setelah itu, Notaris juga kan melihat bukti sertifikat sebagai bukti kepemilikan hak atas tanah yang akan dilakukan oleh Wajib Pajak. Dalam hal ini, Notaris harus berhati-hati dan dapat melakukan Pengecekan Sertifikat terlebih dahulu ke BPN dimana letak tanah itu berada untuk melihat apakah Sertifikat tersebut asli dikeluarkan oleh BPN. 
9. Notaris, juga harus mengecek bahwa hak atas tanah yang akan dialihkan tidak melebihi batas maksimal 5 bidang tanah yang dapat dimiliki oleh orang perorangan. Setiap orang dibatasi kepemilikan hak atas tanah Hak Milik maksimal lima bidang atau tidak lebih dari 5000 meter persegi berdasarkan Keputusan Menteri Agraria/Kepala BPN Nomor 6 Tahun 1998 tentang Pemberian Hak Milik Atas Tanah untuk Rumah Tinggal.

10. Setelah data-data yang dibutuhkan lengkap, maka Notaris akan membuat Akta Pernyataan dengan format Akta Notaris sebagaimana yang ada di dalam UUJN yang akan ditandatangani oleh para pihak.

11. Setelah akta ditandatangani, maka Notaris akan mengeluarkan salinan Akta Pernyataan tersebut dan akan dijadikan dasar untuk balik nama ke BPN tempat dimana letak tanah tersebut (harta wajib pajak yang dialihkan) berada.

12. . Adapun persyaratan balik nama di Kantor BPN adalah :

a. Mengisi Surat Permohonan.

b. Asli Sertifikat.

c. Asli Akta Peralihan Hak.

d. Fotocopy KTP Para Pihak.

e. Bukti Pelunasan PBB.

f. Bukti Validasi PPH, dalam hal ini diinput oleh PPAT yang mempunyai akses langsung ke kantor Pajak setempat, dimana letak lokasi tanah itu berada.

g. Dengan tambahan Surat Keterangan Pengampunan Pajak, SKB (Surat Keterangan Bebas) pemotongan dan atau pemungutan Pajak Penghasilan dari Kepala Kantor Pelayanan Pajak.

Pembuatan Akta Pernyataan Notaris sebagai dasar balik nama di BPN, tidak harus dibuat di Notaris dimana letak tanah itu berada, misalnya letak tanah yang menjadi obyek Pengampunan Pajak di Kota Depok, maka yang membuat Akta Pernyatan tersebut, tidak harus Notaris di Kota Depok. Seperti yang dilakukan oleh Notaris Kota Depok Tasya Amanda, SH., M.Kn, dimana obyek hak atas tanah Wajib Pajak berada di Kota Depok, namun dalam pembuatan Akta Pernyataan dibuat oleh Notaris Kabupaten Bogor. Dalam hal ini, Notaris Tasya 
Amanda, SH., M.Kn sebagai Notaris di Kota Depok, membantu dalam proses pengecekan sertifikat di BPN, input BPHTB (Bea Perolehan Hak atas Tanah dan Bangunan) di BKD Kota Depok (karena hanya bisa diinput oleh PPAT Kota Depok), proses validasi dan pendaftaran balik nama di BPN Kota Depok.

Hal ini dikarenakan wilayah kerja Notaris yang berbeda dengan PPAT. Berdasarkan Pasal 18 ayat 2 Undang-Undang Jabatan Notaris, Notaris mempunyai wilayah kerja/wilayah jabatan meliputi seluruh wilayah provinsi dari tempat kedudukannya. Meskipun Notaris membuat akta di luar wilayah Provinsi tempat kedudukannya, asalkan para penghadap hadir dan menandatangani akta tersebut di hadapan Notaris, maka akta tersebut dikatakan sah, asalkan para penghadap memenuhi syarat-syarat yang ditetapkan dalam Pasal 39 Undang-Undang Jabatan Notaris yaitu :

(1.) Penghadap harus memenuhi syarat sebagai berikut :

a. paling rendah berumur 18 (delapan belas) tahun atau telah menikah; dan

b. cakap melakukan perbuatan hukum

(2.) Penghadap harus dikenal oleh Notaris atau diperkenalkan kepadanya oleh 2 (dua) orang saksi pengenal yang berumur paling rendah 18 (delapan belas) tahun atau telah menikah dan cakap melakukan perbuatan hukum atau diperkenalkan oleh 2 (dua) penghadap lainnya.

(3.) Pengenalan sebagaimana dimaksud pada ayat (2) dinyatakan secara tegas dalam Akta." .

Menurut Errizka F Bey, SE, SH, M.Kn, Notaris juga tetap harus berhati-hati dalam Program pengampunan pajak ini, agar dapat melindungi dirinya sendiri di kemudian hari, dengan meminta Wajib Pajak membuat surat pernyataan dari pemilik harta bahwa objek tersebut bukan merupakan hasil kejahatan korupsi dan memuat klausul yang membebaskan notaris dari tuntutan pihak manapun apabila harta obyek Pengampunan Pajak (Tax Amnesty) yang di balik nama ternyata terbukti hasil korupsi. Selain itu, harus disebutkan juga bahwa peralihan hak tersebut dilakukan dalam rangka program Pengampunan Pajak (Tax Amnesty).

Jika tanah yang menjadi obyek pengampunan pajak hanya memiliki bukti tanah berupa girik. Notaris harus melakukan pengecekan ke kelurahan mengenai data fisik dan data yuridis. Selain itu, Notaris juga harus melihat tanggal 
perolehan hak atas tanah milik wajib pajak. Bila ternyata hak atas tanah milik wajib pajak diperoleh setelah tahun 2015 tentunya tidak bisa dilakukan program pengampunan pajak karena perbuatan hukum yang dilakukan sebelum tahun 2015 dan belum dilaporkan oleh wajib pajak dalam SPT sebelumnya bukan merupakan obyek Program Pengampunan Pajak.

Dalam Program Pengampunan Pajak (Tax Amnesty) ini, Wajib Pajak juga dibebaskan dari pengenaan Pajak Penghasilan (PPh) apabila harta tersebut belum dibaliknamakan oleh Wajib Pajak sebelum tangga 31 Desember 2017, hal ini diatur berdasarkan ketentuan Pasal 15 ayat 3 dan 4 Undang-Undang Pengampunan Pajak. Untuk dapat memperoleh fasilitas ini, Wajib Pajak harus mempunyai Surat Keterangan Bebas (SKB) dengan melampirkan beberapa dokumen yang dibutuhkan.

Berbeda dengan peralihan hak atas tanah dan bangunan diluar Program Pengampunan Pajak, dimana berdasarkan ketentuan Peraturan Pemerintah Nomor 34 Tahun 2016 tentang Pajak Penghasilan atas Penghasilan dari Peralihan Hak atas Tanah dan atau Bangunan, dan Perjanjian Pengikatan Jual Beli atas tanah dan/atau Bangunan Beserta Perubahannya, dimana bagi penjual harus membayar pajak penjualan atas peralihan hak atas tanah dan bangunan senilai 2,5\% dari nilai transaksi perlaihan hak atas tanah (minimal harga NJOP).

Sedangkan untuk BPHTB, Wajib Pajak yang mengikuti Program Pengampunan Pajak tetap harus membayar seperti peralihan hak atas tanah pada biasanya yaitu dengan rumus 5\% x (Nilai Jual Obyek Pajak (NJOP)-Nilai Jual Obyek Pajak Tidak Kena Pajak (NJOPTKP)). Dalam hal ini, Notaris juga berperan untuk menginput BPHTB agar dapat divalidasi pajak BPHTBnya.

\section{H. Implikasi Akta Pernyataan Notaris terhadap Peralihan Hak atas Tanah dalam Program Pengampunan Pajak (Tax Amnesty)}

Bagi Wajib Pajak yang membeli tanah atau dan bangunan masih memakai nama orang lain (nominee) dapat mengakui kembali harta tersebut dan melaporkan sebagai harta sahnya, sehingga Wajib Pajak dapat melaporkan dan membayar pajaknya sesuai dengan keadaan yang sesungguhnya. Program pengampunan pajak merupakan kesempatan untuk penghapusan pajak yang terutang, tidak dikenai sanksi administrasi perpajakan dan sanksi pidana di bidang 
perpajakan, dengan cara mengungkap harta dan membayar uang tebusan sebagaimana diatur dalam Undang-Undang Nomor 11 Tahun 2006 Tentang Pengampunan Pajak (Tax Amnesty). ${ }^{17}$

Kewenangan yang diamanatkan oleh Undang-Undang Pengampunan Pajak ini, memberi tugas baru bagi Notaris. Selama ini menurut ketentuan yang berlaku dalam Pasal 37 ayat 1 Peraturan Pemerintah Nomor 24 Tahun 1997 tentang Pendaftaran Tanah, PPAT yang berwenang membuat akta peralihan hak atas tanah dan hak milik atas satuan rumah susun melalui jual beli, tukar menukar, hibah, pemasukan dalam perusahaan dan perbuatan hukum pemindahan hak lainnya, kecuali pemindahan hak melalui lelang. Pendaftaran peralihan hak atas tanah di BPN selama ini dilakukan berdasarkan akta yang dibuat oleh PPAT.

Akta Pernyataan Bersama yang dibuat oleh Notaris dalam Program Pengampunan Pajak sebagaimana yang diamanatkan dalam Pasal 15 ayat 2 Undang-Undang Pengampunan Pajak masuk ke dalam peralihan hak atas tanah yang dialihkan karena menunjuk pada berpindahnya hak atas tanah melalui perbuatan hukum yang sengaja dilakukan oleh para pihak. Berpindahnya hak atas tanah tersebut, dialihkan dari orang lain yang namanya dipinjam dalam pemilikan hak atas tanah (nominee) kepada Wajib Pajak yang mengikuti Program Pengampunan Pajak (Tax Amnesty).

Ada 2 bentuk akta otentik yang dibuat oleh Notaris, yaitu :

a.) Akta parte atau partij acte.

Akta parte ialah akta yang dibuat oleh para pihak dihadapan pejabat umum (notaris) yang berkuasa untuk itu ditempat dimana akta itu dibuat. Dalam akta ini notaris hanya menuangkan kehendak dan kemauan para pihak yang merupakan isi dari akta tersebut. Isi dalam akta bukanlah keinginan notaris, tetapi keinginan dari para pihak yang tertuang dalam akta tersebut, peran notaris hanyalah memberikan otentisitas pada akta tersebut.

b.) Akta pejabat atau Ambtelijke acte/procesverbaal acte/relaas acte.

\footnotetext{
${ }^{17}$ Imelda Agung dan Endang Sri Kawuryan, Implikasi Akta Nominee sebagai Dasar Permohonan Pengampunan Pajak, Al Daulah : Jurnal Hukum dan Perundangan Islam, Fakultas Syari'ah dan Hukum UIN Sunan Ampel Surabaya. Volume 7 Nomor 2, Oktober 2017, hal. 488.
} 
Akta pejabat ialah akta yang dibuat oleh notaris sebagai pejabat umum yang memuat uraian secara otentik tentang semua peristiwa atau kejadian yang dilihat, dialami, dan disaksikan oleh notaris sendiri dalam menjalankan jabatannya. Misalnya akta berita acara dan akta risalah.

Akta Pernyataan Bersama yang dibuat oleh Notaris dalam Program Pengampunan Pajak adalah Akta Parete, notaris hanya menuangkan kehendak dan kemauan para pihak yang merupakan isi dari akta tersebut. Isi dalam akta bukanlah keinginan notaris, tetapi keinginan dari para pihak yang tertuang dalam akta tersebut, peran notaris hanyalah memberikan otentisitas pada akta tersebut. Akta.

Akta Pernyataan Bersama yang dibuat oleh Notaris mempunyai kekuatan pembuktian lahir. Apa yang lahir tampak sebagai akta otentik haruslah diterima atau dianggap demikian sampai terbukti sebaliknya : acta publica probant sese ipsa. Kekuatan pembuktian dari akta otentik dapat dibedakan antara : Akta otentik yang dibuat oleh Notaris mengandung konsep kebenaran dimana akta otentik tersebut tidak hanya membuktikan bahwa para pihak sudah menerangkan apa yang dituliskan didalam akta tersebut, tetapi juga bahwa apa yang diterangkan dalam akta tersebut adalah benar. Kemudian, akta otentik dapat dikatakan memiliki kekuatan pembuktian yang sempurna karena memiliki tiga kekuatan pembuktian, yaitu kekuatan pembuktian lahiriah, kekuatan pembuktian formil, dan kekuatan pembuktian material.

Menurut Tasya Amanda, SH., M.Kn, Akta Pernyataan Bersama yang dibuat oeh Notaris dapat dijadikan dasar peralihan hak atas tanah dan bangunan (balik nama) di BPN setempat, sebagaimana akta-akta yang dibuat oleh Pejabat Pembuat Akta Tanah (PPAT) sebagai dasar Pendaftaran Tanah, atas perbuatan hukum :

1.) Jual beli;

2.) Tukar menukar;

3.) Hibah;

4.) Pemasukan ke dalam perusahaan (inbreng);

5.) Pembagian hak bersama; 
6.) Pemberian Hak Guna Bangunan/Hak Pakai atas tanah Hak Milik;

7.) Pemberian Hak Tanggungan;

8.) Pemberian kuasa membebankan Hak Tanggungan.

Akta Pernyataan Bersama yang dibuat oleh Notaris berdasarkan kesepakatan wajib pajak dan orang lain yang namanya dipinjam dalam pemilikan hak atas tanah (nominee) berimplikasi terhadap peralihan hak atas tanah yang dialihkan, sehingga obyek hak atas tanah tersebut, dapat dibaliknamakan ke pemegang hak yang sebenarnya, yaitu Wajib Pajak.

Meskipun kewenangan pembuatan akta otentik yang berkaitan dengan peralihan hak atas tanah ini dilimpahkan kepada Notaris, namun Akta Pernyataan Bersama ini, memiliki implikasi terhadap peralihan hak atas tanah hanya dalam Program Pengampunan Pajak (Tax Amnesty). Hal ini berkaitan dengan kewenangan Notaris dalam pembuatan Akta Pernyataan berdasarkan ketentuan Undang-Undang Pengampunan Pajak. Setelah Program Pengampunan Pajak (Tax Amnesty) ini berakhir di tanggal 31 Maret Tahun 2017. Notaris tidak mempunyai kewenangan dalam pembuatan akta pernyataan yang berimplikasi terhadap peralihan hak atas tanah dan bangunan. Akta Otentik terhadap peralihan hak atas tanah, yang dapat dijadikan dasar pendaftaran peralihan hak atas tanah di BPN tetaplah menjadi kewenangan Pejabat Pembuat Akta Tanah sebagaimana yang diamanatkan dalam 1 Peraturan Pemerintah Republik Indonesia Nomor 24 Tahun 2016 Tentang Perubahan Atas Peraturan Pemerintah Nomor 37 Tahun 1998 Tentang Peraturan Jabatan Pejabat Pembuat Akta Tanah dan Peraturan Pemerintah Nomor 24 Tahun 1997 tentang Pendaftaran Tanah. 


\section{PENUTUP}

\section{Kesimpulan}

1. Notaris memiliki peran yang sangat penting dalam Program Pengampunan Pajak (Tax Amnesty) mulai dari menuangkan perjanjian balik nama atau pengalihan harta ke dalam bentuk Akta Pernyatan hingga melegalisasi dokumen penting untuk Program Pengampunan Pajakseperti Surat Pernyataan Harta untuk Pengampunan Pajak.

2. Akta Pernyataan Bersama yang dibuat oleh Notaris, memiliki implikasi terhadap peralihan hak atas tanah hanya dalam Program Pengampunan Pajak (Tax Amnesty). Setelah Program Pengampunan Pajak (Tax Amnesty) ini berakhir, Notaris tidak mempunyai kewenangan dalam pembuatan akta otentik yang berimplikasi terhadap peralihan hak atas tanah. 


\section{DAFTAR PUSTAKA}

Buku

Adjie, Habib.Hukum Notaris Indonesia, Tafsir Tematik Terhadap UU No.30 Tahun 2004 Tentang Jabatan Notaris, Bandung: Rafika Aditama, 2008.

. Kebatalan dan Pembatalan Akta Notaris, Bandung : Refika Aditama, 2013.

Prajidno, A.A.Andi. Apa dan Siapa Notaris di Indonesia ?, Cetakan Pertama, Surabaya : Putra Media Nusantara, 2010.

Tobing, G.H.S. Lumban. Peraturan Jabatan Notaris, Jakarta, Erlangga, 1983.

Santoso, Urip. Pendaftaran dan Peralihan Hak atas Tanah, Cetakan I, Jakarta : Prenada Media Group, 2010.

Soekanto, Soerjono. Pengantar Penelitian Hukum, Jakarta : UI Press, 2006.

\section{Artikel}

Agung Imelda dan Endang Sri Kawuryan, Implikasi Akta Nominee sebagai Dasar Permohonan Pengampunan Pajak, Al Daulah : Jurnal Hukum dan Perundangan Islam, Fakultas Syari'ah dan Hukum UIN Sunan Ampel Surabaya, Volume 7 Nomor 2, Oktober 2017.

\section{Peraturan Perundang-undangan}

Kitab Undang-Undang Hukum Perdata.

Undang-Undang Nomor 5 Tahun 1986 tetang Peradilan Tata Usaha Negara.

Undang-Undang Nomor 30 Tahun 2004 tentang Jabatan Notaris.

Undang-Undang Nomor 16 Tahun 2009 tentang Ketentuan Umum dan Tata Cara Perpajakan.

Undang-Undang Nomor 2 Tahun 2014 tentang Perubahan atas Indonesia, Undang-Undang Nomor 11 Tahun 2016, Tentang Pengampunan Pajak.

Peraturan Pemerintah Nomor 24 Tahun 1997 tentang Pendaftaran Tanah.

Peraturan Pemerintah Republik Indonesia Nomor 24 Tahun 2016 Tentang Perubahan Atas Peraturan Pemerintah Nomor 37 Tahun 1998 Tentang Peraturan Jabatan Pejabat Pembuat Akta Tanah (PPAT). 


\section{Internet}

Arief Rachman, Akta Otentik dalam Hukum Positif di Indonesia, https://notarisarief.wordpress.com/2011/05/15/akta-otentik-dalam-hukumpositif-indonesia, diakses 28 September 2018.

Tax Amnesty Indonesia 2016, "Latar Belakang dan Tujuan Tax Amnesty", http://taxamnestyindonesia2016.blogspot.com/2016/08/latar-belakangdan-tujuan-tax-amnesty.html, diakses 20 Februari 2018.

Zulham Umar, Kewenangan, Kewajiban Dan Larangan Notaris Dalam UUJN, https://zulpiero.wordpress.com/2010/04/26/kewenangan-kewajiban-danlarangan-notaris-dalam-uujn/, diakses 29 Oktober 2018. 